\title{
Indentifikasi Karakteristik Morfologi dan Produktivitas Beberapa Jenis Tanaman Tomat (Lycopersicum esculentum) di Dataran Rendah
}

\section{Identification of Morphological Characteristics and Productivity of Several Types of Tomato Plants (Lycopersicum Esculentum) in the Lowlands}

\author{
Syarifah Phatia Shabira ${ }^{1}$, Agam Ihsan Hereri ${ }^{1}$, Elly Kesumawati ${ }^{*}$ \\ ${ }^{1}$ Jurusan Agroteknologi, Fakultas Pertanian, Universitas Syiah Kuala
}

\begin{abstract}
Abstrak. Tomat cherry memiliki keunggulan ekonomis dibandingkan tomat jenis lain. Keunggulan terletak pada harga jual yang tinggi dan relatif stabil. Tomat yang dibudidayakan di daerah tropis cenderung lebih produktif di dataran tinggi dari pada di dataran rendah. Untuk mengimbangi permintaan tersebut maka budidaya tomat perlu terus dikembangkan, baik secara perluasan areal penanaman maupun perbaikan sifat genetik tanaman.Penelitian ini bertujuan untuk mengidentifikasikan karakteristik morfologi dan hasil beberapa jenis tanaman tomat di dataran rendah, dimana kondisi lingkungan yang berbeda dengan kondisi asal tanaman tersebut. Penelitian ini menggunakan Rancangan Acak Kelompok pola non faktorial dengan perlakuan jenis tanaman tomat, yang terdiri dari 6 jenis tanaman tomat dengan 3 ulangan yang ditanam di Gampong Lamgugop, Kecamatan Syiah Kuala, Kota Banda Aceh pada bulan Juli 2017 sampai dengan bulan Januari 2018. Adapun jenis tanaman tomat cherry yang digunakan adalah Indigo Sun (Chile), Italian Tree (Italia), Black Krim (Ukraina), JPN-1 dan Momotaro (Jepang), Serta TVF-134 (Thailand).Hasil penelitian menunjukkan terdapat pertumbuhan karakteristik morfologi yang belum optimal pada fase generatif tanaman tomat. Jenis tanaman tomat yang dapat beradaptasi dari karakteristik morfologi, pertumbuhan dan hasil di dataran rendah Banda Aceh adalah Indigo Sun, JPN-1, dan Momotaro. Hasil analisis 6 jenis tanaman tomat menunjukkan bahwa jumlah buah per tanaman terbanyak terdapat pada jenis JPN-1 dengan rata-rata 4,83 buah. Tanaman tomat jenis Momotaro yang memiliki nilai rata-rata berat buah terbanyak dan diameter buah terbesar, yaitu sebesar $13,47 \mathrm{~g}$ dan $12,35 \mathrm{~mm}$.
\end{abstract}

Kata kunci: Jenis Tomat, Morfologi, Produktivitas, Dataran Rendah.

\begin{abstract}
Cherry tomatoes have more economic advantage than other types of tomatoes. The advantage lies in the high selling price and relatively stable. Cultivated tomatoes in the tropics land to be more productive in the highlands than in the lowlands.to compensate for this demand, tomato cultivation needs to continue to be developed, both in expanding the area and improving the genetic properties of plant. This study aims to identify the morphological characteristics and the result of several types of tomato plants in the lowlands, in wich the evironmental coditions are different from the conditions of origin of the plant. This study used a non factorial randomized block design with the treatment of tomato plant wich consists of 6 types tomato plant with 3 replications planted in Gampong Lamgugob, Sub District of Syiah Kuala Banda Aceh on july 2017 until januari 2018. The types of cherry tomato plamt used are Indigo Sun (Cile), Italian Tree (Italia), Black Krim (Ukraina), JPN-1, Momotaro (Japan), adn TVF-134 (Thailand). The result showed that there were growth in morphological characteristics were not optimal in the generative phase of tomato plant. The tomato plants that can adapt to morphological characteristics, growth and yield in the lowlands are Indigo Sun, JPN1, and Momotaro. The result of analysis of 6 types of tomato plant showed that the highest number of fruits each plant was found in the JPN-1 with an average about 4,84 fruit. Momotaro tomato plants have the highest average fruits weight and the largest diameter $13,47 \mathrm{~g}$ and $12,35 \mathrm{~mm}$.
\end{abstract}

Keywords: Tomato Type, Morphology, Productivity, Lowlands.

\section{PENDAHULUAN}

Tanaman tomat berasal dari Benua Amerika, tersebar dari Amerika Tengah hingga Amerika Selatan. Tanaman tomat pertama kali dibudidayakan oleh suku Aztec dan suku 
Inca pada tahun 700 SM. Penyebaran tomat di Indonesia dimulai dari Filipina dan Negaranegara Asia lainnya pada abad ke-18 (Wiryanta, 2002).

Komoditas tomat Indonesia ditingkat regional ASEAN memiliki prospek yang baik, menempati urutan keuda setelah Malaysia. Dengan luas panen dan produksi terbanyak se ASEAN. Luas panen dan produksi tomat Indonesia masih kalah bersaing dibandingkan negara-negara lain ditingkat dunia (FAO, 2011).

Menurut Badan Pusat Statistik (2017) produksi tanaman tomat di Indonesia tahun 2015 mencapai 877.792 ton, dari luas areal tanam sebesar 54.554 ha, dengan produktivitas 16,09 ton/ha. Sedangakan tahun 2016 produksi tomat Indonesia mencapai 883.233 ton, dari luas areal tanam sebesar 57.688 ha, dengan produktivitas 15,31 ton/ha. Produksi tomat di Aceh pada tahun 2015 mencapai 210.924 ton dengan luas areal tanam 946 ha dengan produktivitas 218,80 ha dan pada tahun 2016 produksi tanaman tomat meningkat sebesar 256.473 ton namun luar areal tanam menurun sebesar 811 dengan produktivitas 316,24 ton/ha.

Tanaman tomat umumnya hidup di dataran tinggi, namun meningkatnya kebutuhan masyarakat untuk konsumsi diperlukan perluasan areal tanam yaitu di dataran rendah. Tanaman tomat yang hidup di dataran rendah masih banyak dijumpai penurunan produksinya yang diakibatkan ketidakmampuan tanaman tersebut terhadap lingkungan (Wijayani dan Widodo, 2005). Upaya pengembangan tomat di Aceh dari setiap tahunnya mengalami peningkatan, sejalan dengan permintaan pasar yang tinggi. Untuk mengimbangi permintaan tersebut maka budidaya tomat perlu terus dikembangkan, baik secara perluasan areal penanaman maupun perbaikan sifat genetik tanaman. Namun, terdapat kendala terhadap pengembangan budidaya tomat pada dataran rendah yaitu, kurangnya varietas unggul yang cocok untuk dibudidayakan didataran rendah (Purwati dan Khairunisa,2007).

Tomat cherry merupakan salah satu jenis tomat yang sering dikonsumsi. Tomat cherry memiliki keunggulan ekonomis dibanding yang lain. Keunggulan terletak pada harga jual yang tinggi dan relatif stabil (Fitriani, 2012). Budidaya tomat cherry dengan sistem konvensional tidak berbeda dengan membudidayakan tomat jenis lain. Budidaya tomat cherry secara konvesional ini sangat bergantung dengan alam, sehingga menyebabkan fluktuasi produktivitas tomatcherry (Yamin, 2012).

Poehlman dan Sleeper (1995) menyatakan, salah satu upaya yang dapat dilakukan untuk meningkatkan hasil produksi tomat didataran rendah adalah dengan perakitan varietas unggul yang cocok dibudidayakan di dataran rendah. Namun, Varietas tomat yang ada sampai saat ini pengembangannya belum spesifik agroklimat, dan mengakibatkan produktivitas tomat menjadi belum optimal.

Penelitian ini bertujuan untuk mengidentifikasikan karakteristik morfologi dan hasil beberapa jenis tanaman tomat di dataran rendah, dimana kondisi lingkungan yang berbeda dengan kondisi asal tanaman tersebut.

\section{METODE PENELITIAN}

\section{Tempat dan Waktu Penelitian}

Penelitian ini telah dilaksanakan di Gampong Lamgugop, Kecamatan Syiah Kuala, Kota Banda Aceh dan Laboratorium Hortikultura Fakultas Pertanian Universitas Syiah

Indentifikasi Karakteristik Morfologi dan Produktivitas Beberapa Jenis Tanaman Tomat (Lycopersicum esculentum) di Dataran Rendah (Syarifah Phatia Shabira, Agam Ihsan Hereri, Elly Kesumawati)

Jurnal Ilmiah Mahasiswa Pertanian Unsyiah, Vol. 4, No. 2, Mei 2019: 51-60 
Kuala Banda Aceh, dengan ketinggian tempat 4 mdpl. Penelitian dilakukan pada bulan Juli 2017 sampai dengan Januari 2018.

\section{Bahan dan Alat Penelitian}

Alat yang digunakan dalam penelitian ini adalah cangkul, ayakan tanah ukuran 9 mesh, gembor, handspayer dengan volume 2,5 liter, kayu ajir, tali plastik, gunting, kamera digital Sony W830, leaf area meter merek Mangal model GA-5, jangka sorong, meteran pita, timbangan digital merek Kren EW dan alat tulis.

Bahan yang digunakan dalam penelitian ini adalah 6 jenis benih tomat (Indigo Sun (Cile), Italian Tree (Italia), Black Krim (Ukraina), JPN-1 (Jepang), TVF-134 (Thailand) dan Momotaro (Jepang)). Masing-masing jenis tomat menggunakan 15 butir benih. Pupuk majmuk NPK Mutiara 15:15:15 diperlukan sebanyak 108 g, Pupuk organik (kompos) diperlukan sebanyak $120 \mathrm{~kg}$. Tanah top soil untuk media tanam diperlukan sebanyak 240 $\mathrm{kg}$. Insektisida Profenos dan fungisida Mankozeb. Polibag ukuran 40 x $50 \mathrm{~cm}$ dalam kondisi terlipat (untuk penelitian) dan ukuran 4 x $6 \mathrm{~cm}$ (untuk pembibitan).

\section{Rancangan Penelitian}

Percobaan ini menggunakan Rancangan Acak Kelompok (RAK) pola non faktorial yang terdiri dari 6 jenis tomat dengan 3 ulangan. Setiap ulangan terdapat 2 unit tanaman dengan jarak antar tanaman $50 \times 40 \mathrm{~cm}$ sehingga diperoleh 36 tanaman. Adapun faktor perlakuan varietas pada penelitian ini adalah : $\mathrm{V}_{1}=$ Indigo Rose (Cile), $\mathrm{V}_{2}=$ Italian Tree (Italia), $\mathrm{V}_{3}=$ Black Krim (Ukraina), $\mathrm{V}_{4}=\mathrm{JPN}-1$ (Jepang), $\mathrm{V}_{5}=\mathrm{TVF}-134$ (Thailand), dan $\mathrm{V}_{6}=$ Momotaro (Jepang).

\section{Pelaksanaan Penelitian}

Benih tomat terlebih dahulu direndam dengan air hangat $40^{\circ} \mathrm{C}$ selama 24 jam untuk masing - masing jenis dengan tujuan meningkatkan daya perkecambahan benih. Kemudian benih tomat yang sudah direndam ditanamkan dalam polibag ukuran $4 \mathrm{~cm} \times 6 \mathrm{~cm}$ dengan campuran tanah dan pupuk kandang (1:1) dan dipelihara selama 25 hari setelah semai.Bibit yang sudah berumur 25 hari setelah semai, dipindahkan ke dalam polibag penelitian dengan jarak tanam $50 \times 40 \mathrm{~cm}$ pada sore hari untuk menghindari stress dan bibit dapat beradaptasi. Bibit yang ditanam harus memiliki pertumbuhan baik dengan adanya daun 3-4 helai. Pemupukan dilakukan dengan pemberian pupuk NPK 15:15:15 dengan dosis $3 \mathrm{~g} /$ tanaman yang dibagi 3 kali pemberian. Pemupukan pertama diberikan saat pindah tanam dengan cara melarutkan $0,5 \mathrm{~g}$ pupuk dalam $60 \mathrm{ml}$ air yang diberikan per tanaman, pupuk susulan diberikan pada umur tanaman 28 hari setelah tanam (HST) sebanyak $1 \mathrm{~g}$, dan pada umur tanaman 50 HST sebanyak $1.5 \mathrm{~g}$ dengan cara ditaburkan disekeliling tanaman.

\section{Pemeliharaan}

Pemeliharaan tanaman meliputi penyiraman, penyulaman, pengajiran, penyiangan, dan pengendalian organisme peganggu tanaman (OPT).

\section{Parameter Pengamatan}

Parameter yang diamati pada penelitian ini mengacu pada IPGRI (International Plant Genetic Resources Institute) tahun 1995 yang meliputi : 


\section{Karakteristik Vegetatif}

Pengamatan karakter vegetatif meliputi : Warna batang, Tipe habitus tanaman,Warna daun, dan Bentuk daun.

\section{Karakteristik Generatif}

Pengamatan karakter generatif meliputi : Warna mahkota bunga, Warna buah muda, Warna buah masak, Bentuk buah, Bentuk bahu buah, dan Buah penampang melintang.

\section{Pertumbuhan dan Hasil Jenis Buah}

Pengamatan pertumbuhan dan hasil meliputi : Tinggi tanaman, Diameter batang, Luas daun, Jumlah mahkota bunga, Jumlah buah per tandan, Jumlah buah pertanaman, Berat buah, dan Diameter buah.

\section{HASIL DAN PEMBAHASAN}

\section{Identifikasi Karakteristik Morfologi Beberapa Jenis Tanaman Tomat di Dataran Rendah}

Karakteristik pada tanaman bermacam-macam tergantung pada kultivar dan teknik budidaya tanaman tersebut (Gray dan Michaud, 2008). Karakteristik pada tanaman dikendalikan oleh banyak gen yang masing-masing memberi pengaruh kecil pada karakter itu. Karakter ini banyak dipengaruhi oleh lingkungan. Perlu adanya suatu peranan faktor genetik terhadap faktor lingkungan dalam memberikan penampilan akhir atau fenotip yang diamati (Syukur et al., 2012). Karakteristik morfologi yang diamati dalam penelitian ini antara lain karakter vegetatif (warna batang, habitus tanaman, warna daun, dan bentuk daun) dan karakter generatif (warna mahkota bunga, warna buah masak, warna buah masak, bentuk buah, bentuk bahu buah, dan buah penampang melintang).

\section{Karakter Vegetatif Tanaman Tomat}

Tabel 1. Karakter vegetatif warna batang, habitus tanaman, warna dan bentuk daun beberapa jenis tanaman tomat di dataran rendah

\begin{tabular}{lcccc}
\hline \multirow{2}{*}{ Jenis Tomat } & \multicolumn{4}{c}{ Karakter Vegetatif } \\
\cline { 2 - 5 } & Warna & Habitus & Warna & Dentuk \\
& Batang & Tegak & Hijau tua & Daun \\
\hline Indigo Sun & Hijau tua & Tegak & Hijau tua & Standard \\
Italian Tree & Hijau tua & Tegak & Hijau tua & Potato leaf type \\
Black Krim & Hijau tua & Tegak & Hijau tua & Potato leaf type \\
JPN-1 & Hijau tua & Tegak & Hijau tua & Standard \\
TVF-134 & Hijau tua & Tegak & Hijau tua & Pimpinellifolium \\
Momotaro & Hijau tua & & & \\
\hline
\end{tabular}

Hasil penelitian (Tabel 1) menunjukkan bahwa karakter vegetatif seperti warna batang, habitus tanaman, dan warna daun pada beberapa jenis tanaman tomat memiliki karakter yang sama, yaitu warna batang hijau tua, habitus tanaman yang tegak, serta daun

Indentifikasi Karakteristik Morfologi dan Produktivitas Beberapa Jenis Tanaman Tomat (Lycopersicum esculentum) di Dataran Rendah (Syarifah Phatia Shabira, Agam Ihsan Hereri, Elly Kesumawati)

Jurnal Ilmiah Mahasiswa Pertanian Unsyiah, Vol. 4, No. 2, Mei 2019: 51-60 
yang berwarna hijau. Bentuk daun standard pada tanaman tomat lebih dominan terlihat pada setiap jenis tomat. Jenis Black Krim dan JPN-1 memiliki bentuk daun potato leaf type. Sedangkan jenis Momotaro memiliki bentuk daun yang pimpinellifolium. Daun merupakan bagian dari tanaman tomat yang tidak hanya memiliki fungsi fotosintesis dan respirasi, tetapi dapat menjadi daya tarik visual jika dikaitkan dengan fungsinya sebagai tanaman hias.

\section{Karakter Generatif Tanaman Tomat}

Hasil penelitian (Tabel 2) menunjukkan bahwa, karakter generatif warna mahkota bunga tomat memiliki warna yang cenderung orange terdapat pada jenis tomat Black Krim dan JPN-1. Sedangkan pada jenis Indigo Sun dan Momotaro memiliki warna kuning. Selanjutnya terdapat variasi warna pada buah muda yaitu, warna hijau pada jenis tomat JPN-1 dan Momotaro dan variasi antara hijau dan hitam pada buah muda jenis Indigo Sun. Setiap jenis tomat memiliki warna buah yang bervariasi dari buah muda ke buah masak secara fisiologi. Perubahan warna buah masak pada jenis tomat bervariasi seperti pada jenis tomat Indigo Sun memiliki warna hitam dan orange, pada jenis JPN-1 memiliki warna orange, dan pada jenis Momotaro memiliki warna merah.

Tabel 2. Karakter generatif warna mahkota bunga, warna buah muda, warna buah masak, bentuk buah, bentuk pangkal buah, dan penampang melintang buah pada beberapa jenis tanaman tomat di dataran rendah

\begin{tabular}{|c|c|c|c|c|c|c|}
\hline \multirow{2}{*}{$\begin{array}{l}\text { Karakter } \\
\text { Generatif }\end{array}$} & \multicolumn{6}{|c|}{ Jenis Tomat } \\
\hline & Indigo Sun & $\begin{array}{c}\text { Italian } \\
\text { Tree }\end{array}$ & $\begin{array}{l}\text { Black } \\
\text { Krim }\end{array}$ & JPN-1 & TVF-134 & Momotaro \\
\hline $\begin{array}{l}\text { Warna } \\
\text { Mahkota Bunga }\end{array}$ & Kuning & - & Orange & Orange & - & Kuning \\
\hline $\begin{array}{l}\text { Warna Buah } \\
\text { Muda }\end{array}$ & $\begin{array}{c}\text { Hijau + } \\
\text { Hitam }\end{array}$ & - & - & $\begin{array}{l}\text { Hijau } \\
\text { Terang }\end{array}$ & - & $\begin{array}{l}\text { Hijau } \\
\text { Terang }\end{array}$ \\
\hline $\begin{array}{l}\text { Warna Buah } \\
\text { Masak }\end{array}$ & $\begin{array}{c}\text { Hitam + } \\
\text { Orange }\end{array}$ & - & - & Orange & - & Merah \\
\hline Bentuk buah & Sedikit Rata & - & - & Bulat & - & Rata \\
\hline $\begin{array}{l}\text { Bentuk Bahu/ } \\
\text { Pangkal Buah }\end{array}$ & Tidak Rata & - & - & Rata & - & $\begin{array}{l}\text { Tidak } \\
\text { Rata }\end{array}$ \\
\hline $\begin{array}{l}\text { Penampang } \\
\text { Melintang } \\
\text { Buah }\end{array}$ & Bulat & - & - & Bulat & - & $\begin{array}{l}\text { Tidak } \\
\text { Teratur }\end{array}$ \\
\hline
\end{tabular}

Winarno (1997) menyatakan bahwa warna suatu komoditas mempunyai peran penting dalam mempengaruhi penerimaan konsumen. Pembentukan warna karakter 
generatif ditentukan dengan proses metabolisme, yang memerlukan energi yang diperoleh dari cadangan makanan. Buah tomat mengandung pigmen karotenoid, terutama likopen dan $\beta$-karoten yang merupakan komponen utama penentu warna pada buah tomat masak (Liu et al., 2008).

Bentuk buah juga memiliki perbedaan pada setiap jenis tomat. Bentuk buah sedikit rata terlihat pada jenis tanaman tomat Indigo sun. Jenis tanaman tomat JPN-1 memiliki bentuk bulat dan pada jenis Momotaro memiliki bentuk buah rata. Bentuk pangkal buah tidak rata menjadi dominan pada jenis tanaman tomat Indigo Sun dan Momotaro, sedangkan bentuk pangkal buah rata dijumpai pada jenis tanaman tomat JPN-1. Pada bentuk penampang melintang buah tomat, jenis tanaman tomat Indigo Sun dan JPN-1 mempunyai bentuk bulat, sedangkan jenis Momotaro memiliki bentuk tidak teratur.

\section{Pertumbuhan dan Hasil Beberapa Jenis Tanaman Tomat}

Tinggi tanaman tomat (Tabel 3) menunjukkan bahwa tanaman tomat yang cenderung lebih tinggi pada umur 14, 28, 42, 56, dan 60 HST dijumpai pada jenis JPN-1, dan yang cenderung lebih pendek pada umur 14 dan 28 dijumpai pada jenis tanaman tomat Black Krim, sedangkan pada umur 42, 56, dan 60 HST dijumpai pada jenis tanaman tomat Momotaro. Tinggi tanaman setiap jenis tanaman tomat mengalami fluktuatif, hal ini diduga akibat faktor genetik atau lingkungan asal jenis tersebut. Liptay et al. (1981) menyatakan bahwa ukuran diameter batang dipengaruhi oleh ketersediaan unsur hara, hormon, serta faktor genetik.

Tabel 3. Rata-rata tinggi tanaman, tinggi batang dan diameter batang pada setiap jenis tomat di dataran rendah

\begin{tabular}{llccccc}
\hline Parameter & \multirow{2}{*}{ Jenis Tomat } & \multicolumn{5}{c}{ Umur Tanaman (HST) } \\
\cline { 3 - 7 } & & 14 HST & 28 HST & 42 HST & 56 HST & 60 HST \\
\hline \multirow{2}{*}{ Tinggi } & Indigo Sun $\left(\mathrm{V}_{1}\right)$ & 71,43 & 76,70 & 91,81 & 96,42 & 100,94 \\
Tanaman & Italian Tree $\left(\mathrm{V}_{2}\right)$ & 61,78 & 67,23 & 71,33 & 75,81 & 80,05 \\
$(\mathrm{~cm})$ & Black Krim $\left(\mathrm{V}_{3}\right)$ & 55,82 & 60,23 & 72,19 & 76,97 & 81,60 \\
& JPN-1 $\left(\mathrm{V}_{4}\right)$ & 85,88 & 91,42 & 103,92 & 108,25 & 112,73 \\
& TVF-134 $\left(\mathrm{V}_{5}\right)$ & 68,37 & 72,33 & 76,94 & 81,65 & 88,34 \\
& Momotaro $\left(\mathrm{V}_{6}\right)$ & 57,07 & 61,40 & 67,01 & 71,56 & 76,58 \\
\hline \multirow{5}{*}{ Diameter } & Indigo Sun $\left(\mathrm{V}_{1}\right)$ & 2,42 & 3,91 & 4,64 & 5,98 & 6,86 \\
Batang $(\mathrm{cm})$ & Italian Tree $\left(\mathrm{V}_{2}\right)$ & 2,70 & 4,16 & 5,10 & 6,26 & 7,18 \\
& Black Krim $\left(\mathrm{V}_{3}\right)$ & 2,28 & 4,42 & 5,36 & 6,70 & 7,49 \\
& JPN-1 $\left(\mathrm{V}_{4}\right)$ & 2,36 & 3,67 & 4,56 & 6,02 & 6,83 \\
& TVF-134 $\left(\mathrm{V}_{5}\right)$ & 2,17 & 3,71 & 4,96 & 6,14 & 7,14 \\
& Momotaro $\left(\mathrm{V}_{6}\right)$ & 2,00 & 3,27 & 4,60 & 5,98 & 7,05 \\
\hline
\end{tabular}

Diameter batang tanaman tomat( tabel 3) yang cenderung tinggi pada umur 14 HST dijumpai pada jenis Italian Tree, sedangkan pada umur 28, 42, 56, dan 60 HST dijumpai pada jenis Black Krim, dan yang cenderung pendek dijumpai pada jenis Momotaro.

Indentifikasi Karakteristik Morfologi dan Produktivitas Beberapa Jenis Tanaman Tomat (Lycopersicum esculentum) di Dataran Rendah (Syarifah Phatia Shabira, Agam Ihsan Hereri, Elly Kesumawati)

Jurnal Ilmiah Mahasiswa Pertanian Unsyiah, Vol. 4, No. 2, Mei 2019: 51-60 
Ukuran diameter batang yang besar akan meningkatkan produktivitas tanaman tomat seperti bobot, ukuran, dan jumlah buah tomat. Jenis Indigo Sun, Italian Tree, Black Krim, JPN-1, TVF-134, dan Momotaro berasal dari dataran tinggi sehingga produktivitas akan menurun dan kurang adaktif pada dataran rendah. Perubahan suhu mempengaruhi proses perakaran. Kenaikan suhu menyebabkan serapan hara terhambat sehingga ketersediaan air tanah berkurang. Kebutuhan suhu pada masing-masing tanaman tomat berbeda, suhu ekstrem atau tidak sesuai kebutuhannya akan menyebabkan gangguan pada sifat morfologis dan fisiologis tanaman tomat (Nurwansyah, 2010). Varietas asal dataran tinggi yang dibudidayakan pada dataran rendah akan melakukan penyesuaian lingkungan secara bertahap. Ketidaksesuaian lingkungan atau suhu tinggi secara spontan akan menyebabkan perubahan genetis dalam sel sehingga terjadi perubahan dan mempengaruhi pertumbuhan dan karasteristik tanaman (Bruggemann et al., 1990).

Tabel 4. Hasil rata-rata luas daun, jumlah mahkota bunga, jumlah buah per tandan, jumlah buah per tanaman, berat buah, dan diameter buah setiap jenis tanaman tomat di dataran rendah

\begin{tabular}{|c|c|c|c|c|c|c|c|}
\hline \multirow[b]{2}{*}{$\begin{array}{l}\text { Parameter } \\
\text { Pengamatan }\end{array}$} & \multicolumn{6}{|c|}{ Jenis Tomat } & \multirow[b]{2}{*}{$\begin{array}{l}\mathrm{BNJ} \\
5 \%\end{array}$} \\
\hline & $\begin{array}{c}\text { Indigo } \\
\text { Sun }\end{array}$ & $\begin{array}{l}\text { Italian } \\
\text { Tree }\end{array}$ & $\begin{array}{l}\text { Black } \\
\text { Krim }\end{array}$ & JPN-1 & $\begin{array}{c}\text { TVF- } \\
134\end{array}$ & Momotaro & \\
\hline $\begin{array}{l}\text { Luas Daun } \\
(\mathrm{cm})\end{array}$ & $33,41 \mathrm{~b}$ & $17,68 \mathrm{a}$ & $22,83 \mathrm{ab}$ & $22,11 \mathrm{ab}$ & $\begin{array}{c}28,71 \\
\mathrm{ab}\end{array}$ & $28,65 \mathrm{ab}$ & 14,43 \\
\hline $\begin{array}{l}\text { Jumlah } \\
\text { Mahkota } \\
\text { Bunga (helai) }\end{array}$ & $2.56 \mathrm{c}$ & $2.36 \mathrm{~b}$ & $2.51 \mathrm{c}$ & $2.35 \mathrm{~b}$ & $\begin{array}{c}0,00 \\
(0,71) \mathrm{a}\end{array}$ & $2.55 \mathrm{c}$ & 0,085 \\
\hline $\begin{array}{l}\text { Jumlah Buah } \\
\text { per Tandan } \\
\text { (tandan) }\end{array}$ & $2,39 \mathrm{c}$ & $\begin{array}{c}0,00 \\
(0,71) \mathrm{a}\end{array}$ & $\begin{array}{c}0,00 \\
(0,71) \mathrm{a}\end{array}$ & $2,30 \mathrm{c}$ & $\begin{array}{c}0,00 \\
(0,71) \mathrm{a}\end{array}$ & $1,58 \mathrm{~b}$ & 0,12 \\
\hline $\begin{array}{l}\text { Jumlah Buah } \\
\text { per Tanaman } \\
\text { (buah) }\end{array}$ & $2,65 \mathrm{~b}$ & $\begin{array}{c}0,00 \\
(0,71) \mathrm{a}\end{array}$ & $\begin{array}{c}0,00 \\
(0,71) \mathrm{a}\end{array}$ & $4,83 \mathrm{c}$ & $\begin{array}{c}0,00 \\
(0,71) \mathrm{a}\end{array}$ & $1,78 \mathrm{ab}$ & 1,13 \\
\hline $\begin{array}{l}\text { Berat Buah } \\
(\mathrm{g})\end{array}$ & $7,93 \mathrm{~b}$ & $\begin{array}{c}0,00 \\
(0,71) \mathrm{a}\end{array}$ & $\begin{array}{c}0,00 \\
(0,71) \mathrm{a}\end{array}$ & $4,45 \mathrm{~b}$ & $\begin{array}{c}0,00 \\
(0,71) \mathrm{a}\end{array}$ & $13,34 \mathrm{c}$ & 5,03 \\
\hline $\begin{array}{l}\text { Diameter } \\
\text { Buah }(\mathrm{g})\end{array}$ & $10,05 \mathrm{~b}$ & $\begin{array}{c}0,00 \\
(0,71) \mathrm{a}\end{array}$ & $\begin{array}{c}0,00 \\
(0,71) \mathrm{a}\end{array}$ & $8,33 \mathrm{~b}$ & $\begin{array}{c}0,00 \\
0,71 \mathrm{a}\end{array}$ & $12,35 \mathrm{~b}$ & 7,07 \\
\hline
\end{tabular}

Keterangan: Angka yang diikuti oleh huruf yang sama pada baris yang sama berbeda tidak nyata pada taraf 5\%; Angka yang didalam kurung () merupakan nilai angka transformasi dari $\sqrt{x}+0,5$

Luas daun tomat (Tabel 4) jenis Indigo Sun memiliki nilai tertinggi dibandingkan dengan jenis lainnya yaitu memberikan hasil $33,41 \mathrm{~cm}$. Hal ini diduga karena karakteristik dari jenis daun tersebut memiliki daun yang lebih lebar dari yang lainnya. Daun merupakan 
salah satu organ pada tanaman yang berfungsi dalam penyerapan radiasi cahaya dan proses terjadinya fotosintesis (Buntoro et al., 2014). Sesuai pernyataan Sitompul dan Guritno (1995) bahwa luas daun menentukan laju fotosintesis per satuan tanaman, dan luas daun dapat digunakan untuk mengukur produktifitas biomassa awal tanaman yang berfungsi sebagai modal dalam menghasilkan bahan tanaman baru.

Pada peubah jumlah mahkota bunga jenis tomat didapatkan jumlah mahkota bunga terbanyak pada jenis Indigo Sun yang memiliki rata-rata 2,56. Hal ini diduga akibat pertumbuhan dan produktivitas tanaman yang kurang optimal sehingga menyebabkan kurangnya produksi mahkota bunga. Sejalan dengan penelitian Sitompul dan Guritno, (1995) yang menyatakan bahwa jumlah mahkota bunga adalah salah satu indikator terjadinya pertumbuhan tanaman sebagai data tambahan untuk menjelaskan proses pertumbuhan yang terjadi. Perbedaan jumlah bunga yang dihasilkan pada setiap kultivar dapat dipengaruhi oleh adanya faktor genetik dan faktor lingkungan sekitar pertumbuhan. Karakter - karakter akan terus mendapat respon dan penyesuaian terhadap lingkungan di sekitar penanaman sehingga dapat terjadi perbedaan antara tanaman satu dan yang lainnya (Nazirwan, et al., 2014).

Pada peubah jumlah buah per tandan jenis tomat didapatkan jumlah terbaik pada Indigo Sun yang memiliki rata-rata 2,39 , sedangkan pada peubah jumlah buah per tanaman jenis tomat terbaik didapatkan pada jenis JPN-1 dengan rata-rata 4,83. Hal ini diduga karena pertumbuhan tomat Indigo Sun yang memiliki jumlah tandan yang lebih banyak dari pada jenis lainnya tetapi tidak memiliki jumlah buah per tanaman yang banyak seperti jenis JPN-1 serta terdapat interaksi antara faktor genetik dan lingkungan yang berbeda. (Harjadi (1984); Gardner et al., 1991) bahwa pada setiap jenis tanaman terdapat perbedaan respons genotip terhadap berbagai kondisi lingkungan tumbuh. Keadaan inilah yang membedakan masing-masing jenis. Suryadi dan Permadi,1998; Nazirwan, et al., (2014) juga menyatakan bahwa hasil jumlah buah per tandan pada setiap jenis berbeda akibat adanya pengaruh interaksi antara faktor genetik dan faktor lingkungan.

Pada peubah berat buah dan diameter buah tanaman tomat yang lebih banyak terdapat pada jenis tanaman tomat Momotaro yang memiliki nilai rata-rata berat buah 13,47 g dan diameter buah 12,35 mm. Hal ini terjadi karena jenis tomat Momotaro merupakan tanaman tomat dengan bentuk paling besar daripada jenis tanaman tomat lainnya yang merupakan jenis tanaman tomat cherry. Jenis yang berbeda dapat menunjukkan perbedaan respon pertumbuhan dan hasil.

Pada jenis tanaman tomat Italian Tree, Black Krim, dan TVF-134 tidak memiliki nilai jumlah buah per tandan, jumlah buah per tanaman, berat buah, dan diameter buah sama. Hal ini terjadi karena jenis tanaman tomat Italian Tree, Black Krim, dan TVF-134 tidak memiliki produksi buah, sehingga nilai yang didapatkan bertransformasi. Jenis tanaman tomat yang tidak berproduksi terjadi karena jenis tanaman tomat tidak mampu beradaptasi dengan lingkungan dan dipengaruhi oleh faktor iklim daerah penanaman yang berbeda dengan daerah asalnya, seperti suhu yang dibutuhkan normalnya $20-25^{\circ} \mathrm{C}$ tetapi pada lapangan penelitian suhunya mencapai $26-27^{\circ} \mathrm{C}$, pada kelembaban yang dibutuhkan normalnya $80 \%$ tetapi pada lapangan kelembaban mencapai $80,60 \%$ sehingga terjadinya hasil produksi yang kurang. Sesuai dengan pernyataan Surmaini dan Runtunuwu (2008), salah satu faktor yang mempengaruhi rendahnya produksi di dataran rendah adalah suhu yang lebih tinggi. Perbedaan suhu dapat mengakibatkan perbedaan respon tanaman,

Indentifikasi Karakteristik Morfologi dan Produktivitas Beberapa Jenis Tanaman Tomat (Lycopersicum esculentum) di Dataran Rendah (Syarifah Phatia Shabira, Agam Ihsan Hereri, Elly Kesumawati)

Jurnal Ilmiah Mahasiswa Pertanian Unsyiah, Vol. 4, No. 2, Mei 2019: 51-60 
dimana peningkatan suhu menyebabkan peningkatan transpirasi tanaman sehingga terjadi penurunan produktivitas tanaman, peningkatan konsumsi air, waktu pematangan buah atau biji yang singkat, penurunan mutu hasil, dan pendorong berkembangnya hama penyakit tanaman. Zdravkovic (2011) menyatakan bahwa buah per tanaman merupakan sifat kuantitatif yang dikendalikan oleh banyak gen dan sangat tergantung pada lingkungan. Ismail dan Utomo (1995) menambahkan bahwa hasil maksimum suatu tanaman ditentukan oleh potensi genetik tanaman dan kemampuan beradaptasi dengan lingkungan.

\section{SIMPULAN DAN SARAN}

Hasil penelitian menunjukkan terdapat pertumbuhan karakteristik morfologi yang belum optimal pada fase generatif tanaman tomat. Jenis tanaman tomat yang dapat beradaptasi dari karakteristik morfologi, pertumbuhan dan hasil di dataran rendah Banda Aceh adalah Indigo Sun, JPN-1, dan Momotaro. Hasil analisis 6 jenis tanaman tomat menunjukkan bahwa jumlah buah per tanaman terbanyak terdapat pada jenis JPN-1 dengan rata-rata 4,83 buah. Tanaman tomat jenis Momotaro yang memiliki nilai rata-rata berat buah terbanyak dan diameter buah terbesar, yaitu sebesar 13,47 g dan 12,35 mm. Perlu dilakukan penelitian lanjutan terhadap karakteristik dan produktivitas dari jenis tomat introduksi yang sesuai dengan dataran rendah, mengingat pertumbuhan dan hasil tomat belum optimum.

\section{DAFTAR PUSTAKA}

Badan Pusat Statistik. Produksi Tomat Di Indonesia. 2017. https://www.bps.go.id/. [20 Desember 2018].

Badan Pusat Statistik. Produksi Tomat Didaerah Aceh. 2017. https://www.bps.go.id/site/. [23 Desember 2018].

Bruggemann, W., P.R. Moog, H. Nakagawa, P. Janiesch, and P.J.C. Kuiper,. 1990. Plasma Membrane-bound NADH:Fe ${ }^{3+}$-EDTA reductase and iron deficiency in tomato (Lycopersicon esculentum). Is there a intro reductase Physiol. Plant 79, 339-356.

Buntoro, B.G., R. Rogomulyo, dan S. Trisnowati,. 2014. Pengaruh Takaran Pupuk Kandang dan Intensitas Cahaya terhadap Pertumbuhan dan Hasil Temulawak Putih (Curcuma zedoaria L.). Jurnal Vegetalika, Vol.3 No.4 hlm. 29-39

FAO. 2011. Plant genetic ressource for food and agriculture. Rome. Food and Agriculture Organisation of the United Nations.

Fitriani , E. 2012. Untung Berlipat Budidaya Tomat. Pustaka Baru Press. Yogyakarta.

Gardner, F. P., R. B. Pearce dan R. L. Mitcheil. 1991. Fisiologi Tanaman Budidaya. Universitas Indonesia, Jakarta. $427 \mathrm{hlm}$.

Indentifikasi Karakteristik Morfologi dan Produktivitas Beberapa Jenis Tanaman Tomat (Lycopersicum esculentum) di Dataran Rendah (Syarifah Phatia Shabira, Agam Ihsan Hereri, Elly Kesumawati)

Jurnal Ilmiah Mahasiswa Pertanian Unsyiah, Vol. 4, No. 2, Mei 2019: 51-60 
International Plant Genetic Resource Institute (IPGRI). 1995. Descriptor for Tomato. International Plant Genetic Resource Institute. Roma.

Ismail, T., dan W.H. Utomo. 1995. Hubungan Tanah, Air dan Tanaman. IKIP Press. Semarang.

Liu, L.H., D. Zabaras, L.E. Bennett, P. Aguas, dan B.W. Woonton. 2008. Effects of UV-C, Red Light and Sun Light on The Carotenoid Content and Physical Qualities of Tomatoes During Post-Harvest Storage. Food Chemistry. 115:495-500.

Nazirwan, A. Wahyudi dan Dulbari. 2014. Karakterisasi koleksi plasma nutfah tomat lokal dan introduksi. Jurnal Penelitian Pertanian Terapan 14(1):70-75.

Purwati, E dan Khairunisa. 2007. Budi Daya Tomat Dataran Rendah. Penebar Swadaya, Depok.

Sitompul, S.M dan B. Guritno. 1995. Analisis Pertumbuhan Tanaman. Gadjah Mada University Press, Yogyakarta.

Surmaini, E.E., Runtunuwu, I.L. 2008. Upaya sektor pertanian dalam menghadapi perubahan iklim. J Litbang Pertanian. (30):1-7.

Syukur. M.. S, Sujiprihati. R, Yunianti. 2012. Teknik Pemuliaan Tanaman. Penebar Swadaya. Jakarta.

Winarno FG. 1997. Kimia Pangan dan Gizi. Gramedia Pustaka Utama, Jakarta.

Zdrakovic J, Pavlovic N, Girek Z, Brdr-Jokanovik M, Savic D, Zdrakovic M, Cvikic D. 2011. Generation mean analysis of yield components and yield in tomato (Lycopersicon esculentum Mill.). Pak. J. Bot 43(3):1575-1580. 